\title{
Evidence for the homeostatic regulation of induced beta cell mass expansion
}

\author{
M. A. Lipsett • E. B. Austin • M. L. Castellarin • \\ J. Lemay $\cdot$ L. Rosenberg
}

Received: 30 April 2006 / Accepted: 4 August 2006 / Published online: 3 October 2006

(C) Springer-Verlag 2006

\begin{abstract}
Aims/hypothesis Diabetes results from an insufficient insulin-secreting beta cell mass. Restoration of beta cell mass through pharmaceutically induced endogenous beta cell mass expansion may revolutionise diabetes therapy. However, it remains to be determined whether the induced beta cell mass expansion is under homeostatic regulation.

Methods Beta cell mass expansion rates were derived from three separate studies of continuous stimulation of islet neogenesis, including the partial duct obstruction of euglycaemic Syrian hamsters, administration of a pentadecapeptide with the same amino acid sequence as residues 104-118 of islet neogenesis-associated protein (INGAP ${ }^{104-118}$ ) to euglycaemic Syrian hamsters, as well as to euglycaemic CD-1 mice. The incidence of islet neogenesis, average beta cell size, and beta cell replication and apoptotic rates were determined.

Results Partial duct obstruction led to a $\sim 2.5$-fold increase in endocrine tissue at day $56(p<0.05)$. From day 0 to day 7 the average rate of change of islet area was $12.7 \%$ per day, and this rate decreased to $5.3 \%$ per day from day 7 to day 42 , and to $2.8 \%$ per day from day 42 to day 56 . Administration of INGAP ${ }^{104-118}$ to adult hamsters led to a $31 \%$ increase in total beta cell mass at day $30(p=0.031)$.
\end{abstract}

\footnotetext{
M. A. Lipsett • E. B. Austin · M. L. Castellarin · J. Lemay •

L. Rosenberg

Research Institute of the McGill University Health Centre,

Montreal, QC, Canada

M. A. Lipsett - E. B. Austin - M. L. Castellarin · J. Lemay •

L. Rosenberg $(\triangle)$

Department of Surgery, C9-128 The Montreal General Hospital,

1650 Cedar Avenue,

Montreal, QC H3G 1A4, Canada

e-mail: lawrence.rosenberg@mcgill.ca
}

From day 0 to day 10 the average rate of beta cell mass expansion was $148 \mu \mathrm{g} /$ day, whereas from day 10 to day 30 it decreased to $45 \mu \mathrm{g} /$ day. INGAP ${ }^{104-118}$ administration to adult CD-1 mice resulted in an approximately twofold increase in beta cell mass after 31 days $(p=0.021)$. However, at day 90, there was no significant difference vs age-matched control mice $(p=0.30)$, even though the neogenic beta cell mass was approximately fourfold greater $(p=0.026)$. Beta cell replication was decreased by $56 \%$ $(p<0.048)$, whereas beta cell apoptosis was fourfold greater $(p<0.003)$ in 90 -day INGAP ${ }^{104-118}$-treated mice compared with age-matched control mice.

Conclusions/interpretation These data indicate that in the presence of ongoing islet neogenesis, homeostatic regulatory mechanisms intervene to regulate beta cell mass according to the prevailing metabolic requirements.

Keywords Beta cell mass - Beta cell neogenesis .

Diabetes mellitus - Endogenous progenitor cell therapy ·

Islet neogenesis
Abbreviations
DAB 3,3'-diaminobenzidine tetrahydrochloride
INGAP islet neogenesis-associated protein
PCNA proliferating cell nuclear antigen
PDO partial duct obstruction
TUNEL terminal deoxynucleotidyl transferase-mediated dUTP-biotin nick-end labelling

\section{Introduction}

Diabetes, whether type 1 or type 2 , is arguably a disease ultimately caused by a loss of beta cell mass [1-3]. Over 
the last decade it has been recognised that tight glycaemic control can prevent diabetes-associated complications [4-6]. To date, the only means of achieving such stringent control has been the restoration of beta cell mass through pancreas or islet transplantation, which results in near-perfect control of blood glucose levels without hypoglycaemic episodes that are associated with intensive insulin therapy [7, 8]. Pancreas transplantation is currently far more successful in maintaining long-term reversal of hyperglycaemia than islet transplantation, which is still an emerging technology [9-11]. However, both approaches are limited by the shortage of available organs and the need for chronic immunosuppression. Thus, novel strategies need to be developed that increase the insulin-producing beta cell mass.

An innovative alternative to islet replacement by transplantation is the induction of islet cell neogenesis, i.e. the growth of new insulin-producing cells from noninsulin-producing progenitors. This approach is appealing since the need for organ donation would be removed as a limiting factor. Moreover, the pharmacological induction of islet neogenesis has been confirmed to lead to beta cell mass expansion and reversal of hyperglycaemic states in various animal models [12-15]. However, it is possible that the stimulation of cell differentiation and expansion could potentially lead to the unrestricted growth and hyperfunction that is characteristic of neoplasia [16]. For example, unbridled islet neogenesis, termed nesidioblastosis, was initially reported in 1938 [17]. Similar cellular mechanisms associated with islet neogenesis, including phenotypic dedifferentiation and increased cellular proliferation, are implicit in the transformation of cells to a cancerous state [16]. Moreover, growth factors used to stimulate islet neogenesis have also been associated with various cancers $[16,18-20]$. It is therefore of utmost importance to determine if pharmaceutically induced beta cell mass expansion remains under homeostatic control.

Previous work does indeed suggest that the beta cell mass is responsive to changing metabolic demands. In the pregnant rat the beta cell mass initially expands and then involutes following parturition, closely matching beta cell mass to the prevailing metabolic demands [21, 22]. This regulation of beta cell mass may also be operative in humans, as increased islet neogenesis and beta cell mass expansion in the presence of obesity have been reported [3]. Comparable cell mass regulation has also been observed in lacrimal glands and breast tissue [23-29].

Accordingly, we hypothesise that in the setting of continual induction of islet neogenesis, homeostatic cellular mechanisms regulate beta cell mass to meet the prevailing functional needs. In order to test this hypothesis a new analysis of beta cell mass expansion dynamics was performed using data from two previously reported studies
$[14,30]$. To acquire additional corroborating data, an analysis of chronic pharmacological stimulation of islet cell neogenesis in a third study was performed in which total beta cell mass, neogenic beta cell mass, and average beta cell size, replication and apoptosis were determined.

\section{Materials and methods}

Data from three separate animal studies are reported: (1) partial duct obstruction (PDO) of euglycaemic adult hamsters [30]; (2) administration of a pentadecapeptide with the same amino acid sequence as residues $104-118$ of islet neogenesis-associated protein (INGAP ${ }^{104-118}$ ) to euglycaemic hamsters [14]; and (3) administration of INGAP $^{1104-118}$ to euglycaemic mice. All animal studies were performed in accordance with the guidelines set out by the Canadian Council of Animal Care and McGill University.

Animal models

Partial duct obstruction Experiment 1, first described in 1983, involved the partial duct obstruction of adult female Syrian hamsters (Charles River Breeding Laboratories, Syracuse, NY, USA; $n=24$ ) by performing a midline laporotomy and wrapping the head of the pancreas with a $2-\mathrm{mm}$ wide piece of cellophane tape or sham operation [30]. After 7, 42 and 56 days, hamsters were anaesthetised with sodium pentoarbital, and a thoracotomy performed. Tissues were perfused with a solution of $1 \%$ gluteraldehyde and $4 \%$ formaldehyde, and the pancreas was then removed and post-fixed in $10 \%$ formalin and processed for immunohistochemical analysis.

Administration of INGAP $P^{104-118}$ to euglycaemic hamsters Experiment 2, first described in 2004, involved administration of INGAP ${ }^{104-118}$ (a Reg family member) to 8-week-old female Syrian hamsters (Charles River Breeding Laboratories, St Constant, QC, Canada; $250 \mu \mathrm{g}$ twice daily; $n=30$ ) or an equivalent volume of saline $(n=20)$ [14]. After 10 and 30 days, hamsters were anaesthetised with sodium pentobarbitol (40 mg/kg body weight, i.p.) and killed by exsanguination. The pancreas was removed, blotted on tissue paper, weighed, fixed in $10 \%$ formalin and processed for immunohistochemical analysis.

Administration of INGAP $P^{104-118}$ to euglycaemic mice Experiment 3 involved the administration of INGAP ${ }^{104-118}$ to 6-8-week-old CD-1 mice (Charles River, MA, USA) for 31 days $(0,50,500$ or $2,500 \mu \mathrm{g}$ once daily, i.m.; $n=40)$ or for 90 days $(0,1000,2500$ or $5000 \mu \mathrm{g}$ once daily, s.c.; $n=78$ ). Animals were killed by cervical dislocation, the 
pancreas excised, blotted, weighed, fixed in $10 \%$ formalin and processed for routine immunohistochemistry.

\section{Immunohistochemistry}

Pancreatic sections, 4-5 $\mu \mathrm{m}$ thick, were de-waxed in xylene, and endogenous peroxidase activity was blocked using a 3\% solution of hydrogen peroxide in methanol (for sections to be stained with 3,3'-diaminobenzidine tetrahydrochloride [DAB; Sigma-Aldrich Canada, Oakville, ON, Canada]). Sections were then washed in PBS and incubated with blocking buffer (Zymed Laboratories, San Francisco, CA, USA) for $15 \mathrm{~min}$ at room temperature. Slides were stained with one or more primary antibodies, including insulin (guinea pig anti-porcine, 1:1,000; Dako Diagnostics Canada, Mississauga, ON, Canada); proliferating cell nuclear antigen (PCNA) (mouse anti-rat, clone PC10, 1:100; Dako Diagnostics Canada) and TUNEL detection kit (Roche, Laval, QC, Canada). Slides stained for PCNA and TUNEL were incubated with $0.1 \mathrm{~mol} / 1$ citrate buffer for 9 min at $90^{\circ} \mathrm{C}$ for antigen retrieval before primary antibody application. Slides were incubated with primary antibodies overnight at $4{ }^{\circ} \mathrm{C}$ before being washed in PBS and incubated with the secondary antibodies for $20 \mathrm{~min}$ (Histostain Plus Kit; Zymed Laboratories, San Francisco, CA, USA) or $1 \mathrm{~h}$ (rhodamine-conjugated anti-guinea pig, 1:200; Jackson ImmunoResearch Laboratories, West Grove, PA, USA) at room temperature. After washing in PBS, immunofluorescent sections were cover-slipped using Vectashield (Vector Laboratories, Burlingame, CA, USA) and light sections were incubated with either horseradish peroxidase or alkaline phosphatase conjugate (Histostain Plus Kit) for $20 \mathrm{~min}$, and developed using DAB or New Fuchsin (Dako), respectively. All light immunohistochemical slides were counterstained with Harris' haematoxylin (Sigma-Aldrich) and cover-slipped using Permount (Fisher Scientific, Ottawa, ON, Canada).

Determination of beta cell mass

Percentage beta cell area was determined through analyses of insulin-stained sections as previously described [31,32]. Histological sections were analysed using an Olympus BX60 microscope and Image-Pro Plus software, version 4.0 (Olympus Canada, Markham, ON, Canada; experiments 1 and 2), or using a Zeiss Axioskop 40 microscope and Northern Eclipse software, version 6.0 (Empix Imaging, Mississauga, ON, Canada; experiment 3). Islets from insulin-stained sections were identified, traced and thresholded using the software system to determine the stained tissue area. The total pancreatic tissue area was also measured and the percentage beta cell area calculated. This percentage was then multiplied by the weight of the excised organ to derive the beta cell mass.

Classification of neogenic beta cell mass was performed as previously described $[15,31-33]$. Duct-associated neogenic beta cell structures were categorised as small $\left(<500 \mu \mathrm{m}^{2}\right.$, as determined by the image analysis system) insulin-positive clusters associated with the ductal epithelium (Fig. 1a). Acinar-associated neogenic beta cell structures were categorised as small $\left(<500 \mu \mathrm{m}^{2}\right)$ acinarassociated structures devoid of any other juxtaposed endocrine cells (Fig. 1b). Focal areas of neogenesis were categorised as structures characterised by disorganised insulin-positive staining with apparent infiltration of ductassociated cells (Fig. 1c,d).

For the analysis hamster pancreases with partial duct obstruction (experiment 1), percentage islet area was used as a surrogate for beta cell mass. Briefly, the number of islets per $\mathrm{mm}^{2}$ of pancreatic tissue and the average islet size were determined by manually tracing a minimum of 100 islets per animal. Total islet area was then determined by multiplying the average islet size by the number per $\mathrm{mm}^{2}$.

Determination of beta cell size, replication and apoptosis

Average beta cell size, replication and apoptotic indices were determined for mice administered saline or INGAP $^{104-118}$ for 31 or 90 days $(2,500 \mu \mathrm{g} /$ day $)$ in experiment 3 . The total number of beta cell nuclei and the number of PCNA-positive beta cell nuclei and TUNELpositive beta cell nuclei were determined using the Northern Eclipse image analysis system (Empix Imaging). Average beta cell size was then determined as total insulin area divided by total number of beta cell nuclei for each animal. Beta cell replication indices were determined as the number of beta cell PCNA-positive nuclei divided by total number of beta cell nuclei (average number of nuclei counted/animal: $3670 \pm 411 ; n=5 \mathrm{INGAP}^{104-118}, n=4$ saline for each time point). Apoptotic indices were determined as total number of TUNEL-positive nuclei divided by total number of beta cell nuclei for each animal (average number of nuclei counted/animal: $2,858 \pm 340 ; n=5$ for each time and treatment).

Beta cell mass dynamics

The average daily rate of change of islet area (experiment 1) or beta cell mass (experiment 2) was determined by subtracting the initial value from the islet area of the next time point and dividing by the number of days between time points. Curves predicting islet or beta cell mass expansion dynamics were derived from islet area or beta cell mass from each treatment group, expressed as a percentage of age-matched control animals (Fig. 7). The 
Fig. 1 Insulin-stained sections (brown) from CD-1 mice administered INGAP ${ }^{104-118}$

$(2,500 \mu \mathrm{g} /$ day $)$ for 90 days illustrating small, extra-islet ductassociated beta cell clusters (a), an extra-islet acinar-associated single beta cell (b), and ductassociated focal areas of neogenesis (c,d). Bar $=50 \mu \mathrm{m}$
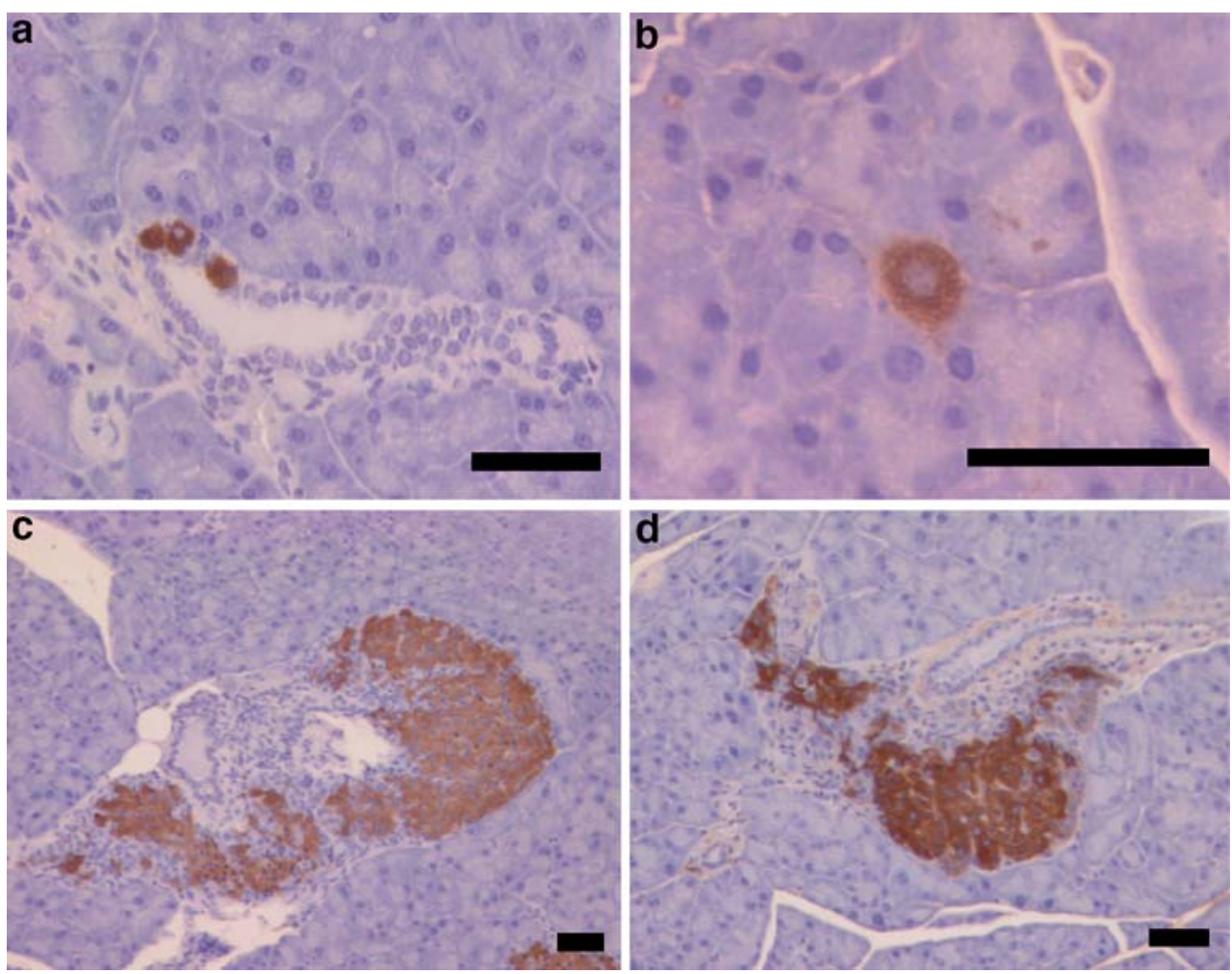

beta cell mass dynamics curve for experiment 3 was constructed using the beta cell mass from mice in the $2,500 \mu \mathrm{g} /$ day group.

\section{Statistical analyses}

All values are reported \pm standard error of measurement. The Student's $t$ test or one-way ANOVA were performed where appropriate. Results with a $p$ value of $<0.05$ were considered significant.

\section{Results}

Following partial duct obstruction, average islet size initially decreased (day 7) before increasing thereafter by $\sim 25 \%$ (day 56, $p<0.05$; Fig. 2a). Islet density (the number of islets per $\mathrm{mm}^{2}$ ), however, was consistently double that of control animals $(p<0.05$; Fig. $2 \mathrm{~b})$, resulting in an approximately 2.5-fold increase in islet area by day $56(p<0.05$; Fig. 2c). From day 0 to 7 , the average rate of change of percent islet area $\left(\mathrm{d}[\%\right.$ islet area $\left.] / \mathrm{d} t_{\text {day }}\right)$ was determined to
Fig. 2 Average islet size (a), islet density (b) and insulin area (percent of total tissue) (c) of hamsters following sham surgery (empty bars, $n=6$ per time point) or partial duct obstruction (filled bars, $n=6$ per time point) ${ }^{*} p<0.05$ vs sham control hamsters. d Daily rate of change of insulin area in hamsters with partial duct obstruction $(n=6$ per time point) a

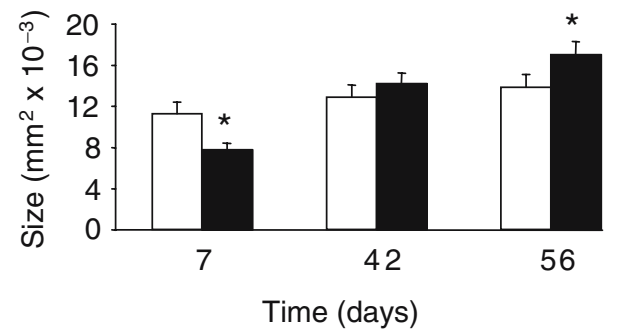

C

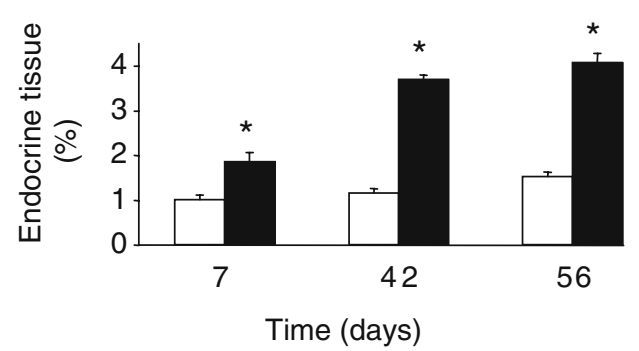

b

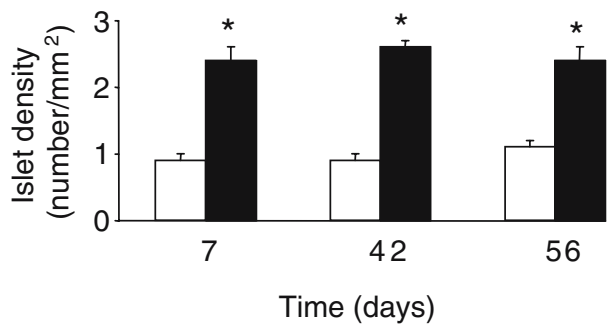

d

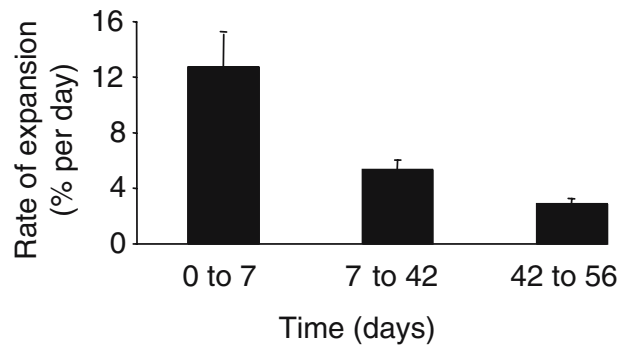


Fig. 3 Total duct-associated beta cell mass (a) extra-islet acinar-associated neogenic beta cell mass (b) and total beta cell mass (c) in hamsters administered saline (empty bars, $n=5$ per time point) or INGAP ${ }^{104-118}$ (filled bars, $n=5$ per time point) for 10 or 30 days. ${ }^{*} p<0.05$ vs saline control. d Daily rate of change of beta cell mass in INGAP $^{104-118}$-treated hamsters ( $n=5$ per time point)

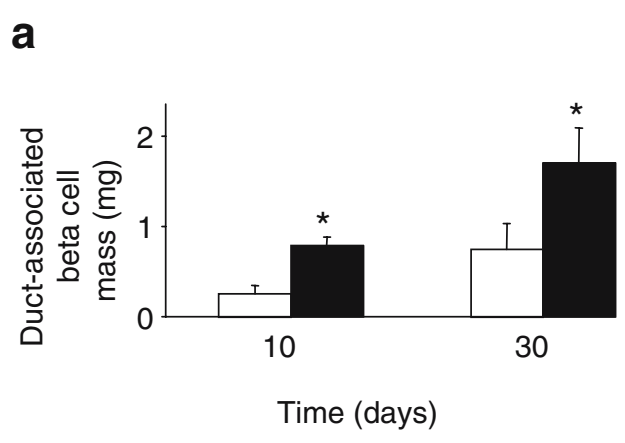

b
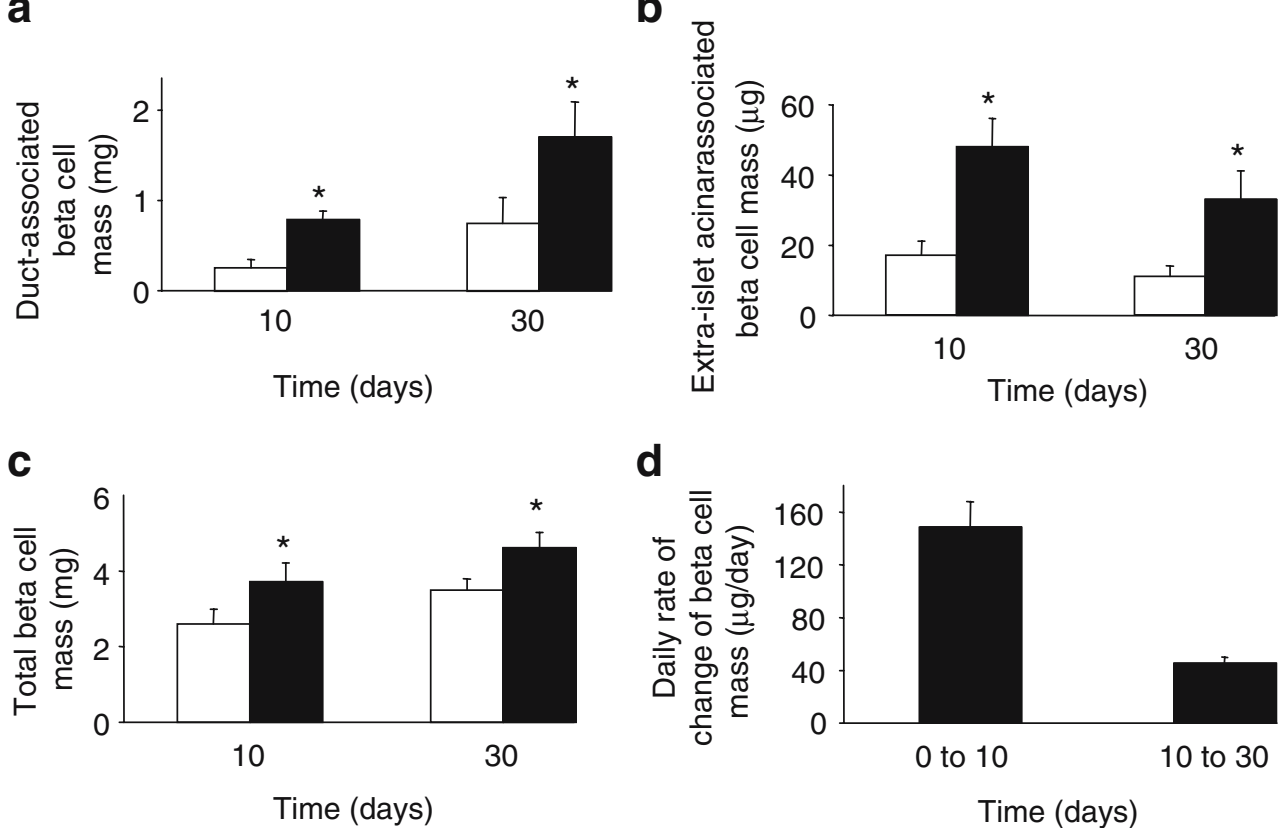

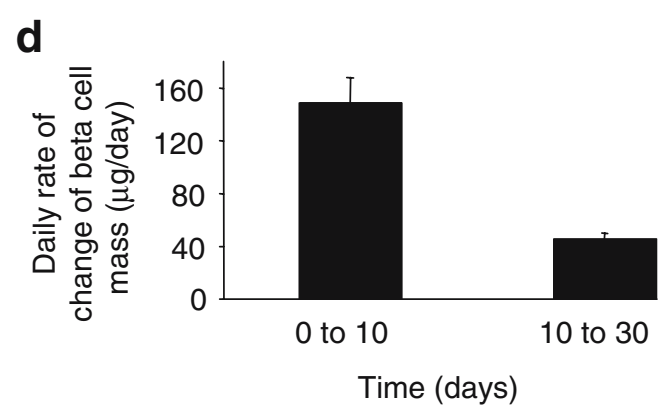

be $12.7 \%$ per day. This rate then declined to $5.3 \%$ per day from day 7 to day 42 , and further to $2.8 \%$ per day from day 42 to 56 (Fig. 2d).

Administration of INGAP ${ }^{104-118}$ to euglycaemic hamsters induced a 2.5-fold increase in total duct-associated beta cell mass ( $p=0.004$; Fig. 3a) and an approximate threefold increase in acinar-associated neogenic beta cell mass ( $p<0.001$; Figs. $1 \mathrm{~b}$ and $3 \mathrm{~b})$ [14]. Total beta cell mass had increased by $44 \%$ at day 10 and $31 \%$ at day 30 relative to saline control hamsters $(p=0.031$; Fig. 3c) [14]. This increase of $44 \%$ corresponds to an initial beta cell mass expansion rate of $148 \mu \mathrm{g} /$ day (from day 0 to day 10 ). The average rate of expansion then decreased to $45 \mu \mathrm{g} / \mathrm{day}$ (from day 10 to 30 ; Fig. 3d) representing a reduction in the rate of beta cell mass expansion of $\sim 70 \%$.

Following the administration of INGAP ${ }^{104-118}$ to euglycaemic CD-1 mice, a dose-dependent increase in total beta cell mass was observed at 31 days (mean total mass: $0.83 \pm 0.09,1.40 \pm 0.25,1.78 \pm 0.37$ and $1.84 \pm 0.36 \mathrm{mg}$ for 0 , 50,500 and 2,500 $\mu \mathrm{g} /$ day, respectively; $p=0.021$; Fig. 4a). At 90 days of treatment there was no difference in total beta cell mass between any of the groups (mean total mass: $1.87 \pm 0.15,1.55 \pm 0.12,1.88 \pm 0.13$ and $1.69 \pm 0.18 \mathrm{mg}$ for 0 , $1,000,2,500$ and 5,000 $\mu \mathrm{g} /$ day, respectively; $p=0.30$;
Fig. 4 a Beta cell mass in CD-1 mice administered saline or INGAP $^{104-118}$ at various doses for 31 days ( $n=10$ per group). b Beta cell mass in mice administered saline or INGAP ${ }^{104-118}$ for 90 days ( $n=20$ per group, except for the $5000 \mu \mathrm{g} /$ day group, where $n=18$ ). c Density of small duct-associated insulin-positive clusters in 90-day-treated animals ( $n=8$ per group). d Density of focal areas of neogenesis in 90 -day treated animals ( $n=8$ per group). ${ }^{*} p<0.05$ vs saline control mice a

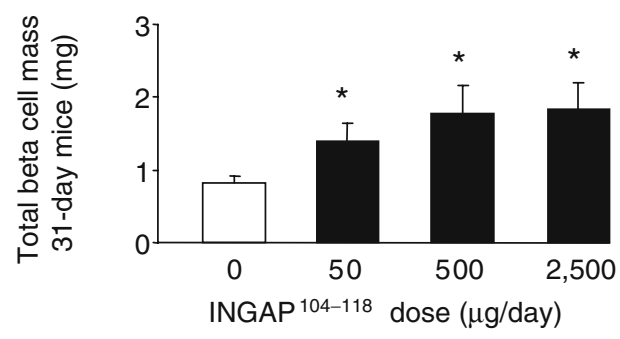

C

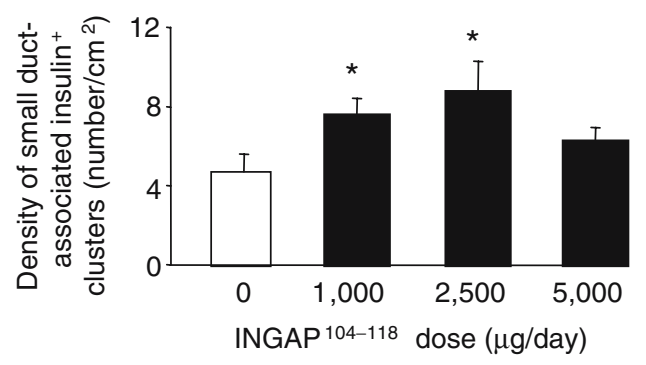

b

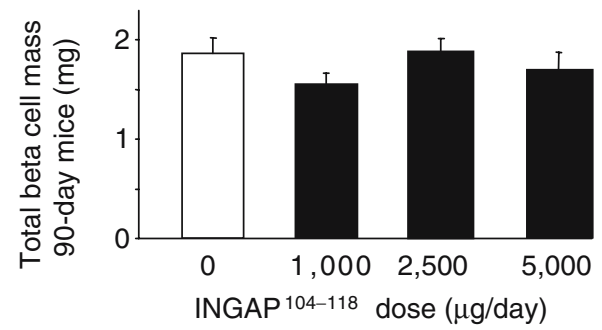

d

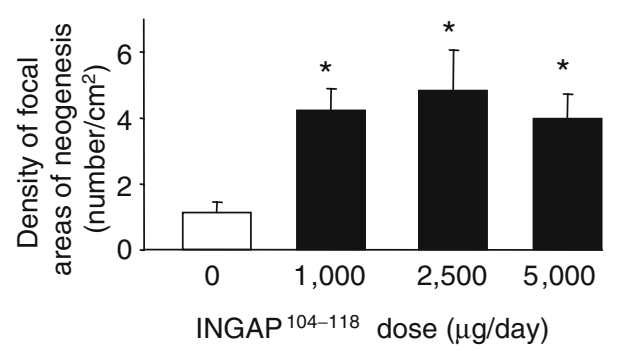


Fig. 4b). The observation that the beta cell mass was not different from control animals at 90 days, despite the persistence of a neogenic stimulus, led us to investigate the potential mechanisms of beta cell mass expansion and involution in the CD-1 mice.

To investigate whether the degree of beta cell neogenesis differed between control mice (saline) and those administered INGAP ${ }^{104-118}$ for 90 days, neogenic structures were quantified from insulin-stained slides. In INGAP ${ }^{104-118}$ treated mice, the number of small duct-associated neogenic structures doubled ( $p=0.029$; Figs. $1 \mathrm{a}$ and $4 \mathrm{c}$ ) and the number of focal areas of neogenesis increased approximately fourfold ( $p=0.008$; Figs. $1 \mathrm{c}, \mathrm{d}$ and $4 \mathrm{~d})$ vs agematched control mice. The neogenic beta cell mass increased by approximately fourfold in INGAP $P^{104-118}$. treated mice compared with that in control mice $(p=0.026$; Fig. 5a). This result, together with the observation that the total beta cell mass of the INGAP ${ }^{104-118}$-treated mice did not differ from that of control animals $(p=0.30$; Fig. $5 b)$ suggests that there is a corresponding increase in beta cell loss to maintain the beta cell mass at control levels (Fig. 5c).

In order to determine if beta cell atrophy, decreased replication or apoptosis could account for this proposed beta cell loss, analyses of average beta cell size, replication rate and apoptotic index of 31-day and 90-day control and INGAP $^{104-118}$-treated mice were performed. There were no significant differences in average beta cell size $(119.1 \pm 5.7$ vs $128.4 \pm 3.9 \mathrm{~mm}^{2}, p=0.18$; Fig. 6a) or replication $(0.66 \pm 0.12$ vs $0.67 \pm 0.16 \%, p=0.94$; Figs. $6 \mathrm{~b}, \mathrm{~d})$ in control vs INGAP ${ }^{104-118}$-treated mice after 31 days, respectively. However, following 90 days of INGAP ${ }^{104-118}$ treatment there was a significant increase in average beta cell size (119.6 \pm 2.5 vs $141.9 \pm 1.2 \mu \mathrm{m}^{2}, p<0.001$; Fig. 6a). Conversely, there was a concomitant decrease of $\sim 50 \%$ in the beta cell replication index $(0.79 \pm 0.17 \%$ vs $0.35 \pm 0.05 \%$, $p=0.048$ ) of INGAP ${ }^{104-118}$-treated mice (Fig. 6b). When beta cell apoptosis was analysed at 31 days by TUNEL, no significant difference was observed between the control and INGAP ${ }^{104-118}$-treated mice $(0.132 \pm 0.027 \%$ vs $0.091 \pm 0.035 \%, p=0.33$, respectively; Fig. $6 \mathrm{c}, \mathrm{e})$. In contrast, following 90 days of treatment there was an approximately fourfold increase in TUNEL-positive beta cells in INGAP ${ }^{104-118}$-treated mice $(0.079 \pm 0.021$ vs $0.313 \pm 0.016 \%, p=0.003$; Fig. $6 \mathrm{c}$ ).

\section{Discussion}

There is accumulating evidence from different animal models suggesting that pancreatic beta cell mass is dynamic and changes to accommodate the body's needs [21, 22, 32, 34-37]. Here we report that regulatory mechanisms do a
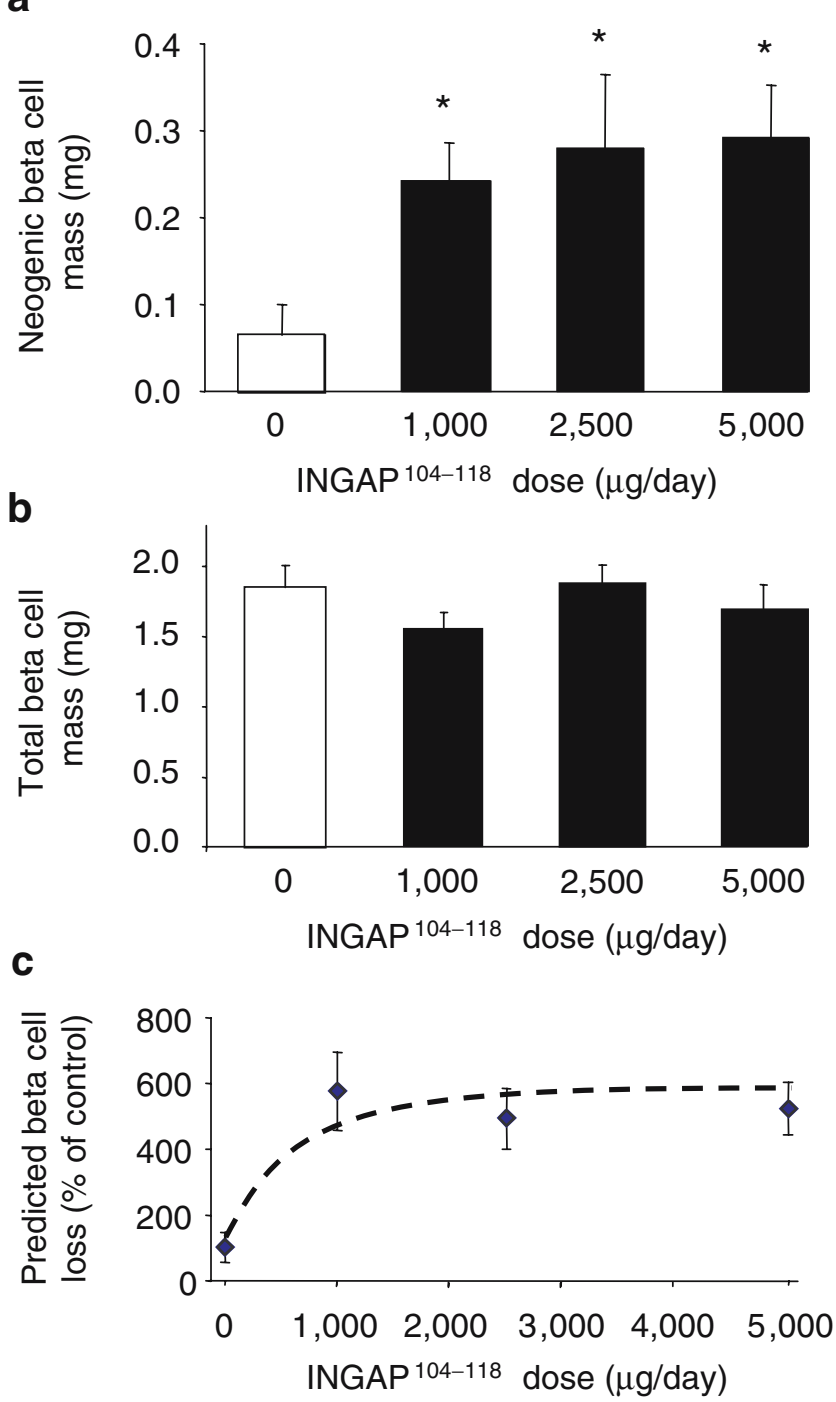

Fig. 5 a Total neogenic beta cell mass from 90-day saline- and INGAP ${ }^{104-118}$-treated mice ( $n=8$ per group). b Total beta cell mass in 90-day saline- and INGAP ${ }^{104-118}$-treated mice. c Predicted net beta cell loss in 90-day INGAP ${ }^{104-118}$-treated mice, derived from values in a and b. ${ }^{*} p<0.05$ vs saline control mice

indeed appear to be operative in the regulation of the insulin-producing beta cell mass, even in the setting of continual stimulation of islet neogenesis. Moreover, the data reported herein suggests that this regulation occurs through decreased beta cell replication and increased beta cell apoptosis.

Although the three studies of induced islet expansion analysed in this report were somewhat different in design, they all shared an initial increase in beta cell mass followed by an involution of this expanded beta cell mass towards age-matched control levels (Fig. 7). This expansion and subsequent involution is similar to that observed during pregnancy and post-partum periods in rodents [21, 22]. During pregnancy the beta cell mass of the gravid female almost doubles in response to the increased metabolic 
Fig. 6 a Average beta cell size in 31- and 90-day saline- (empty bars, $n=4$ per time point) and INGAP $^{104-118}$-treated mice (filled bars, $n=5$ per time point). b Percentage of total beta cell nuclei positive for PCNA in CD-1 mice treated with saline ( $n=4$ per time point) or INGAP $^{104-118}$ for 31 or 90 days ( $n=5$ per time point). c Percentage of total beta cell nuclei positive for TUNEL in CD-1 mice treated with either saline or INGAP $^{104-118}$ for 31 or 90 days ( $n=5$ for each group and time point). d Representative photomicrograph of an insulin and PCNA double-stained pancreatic section from an INGAP ${ }^{104-118}$ treated mouse. e Representative photomicrograph of a TUNELstained pancreatic section from an INGAP ${ }^{104-118}$-treated mouse. $* p<0.05$ vs saline control mice. $\mathrm{Bar}=50 \mu \mathrm{m}$ a

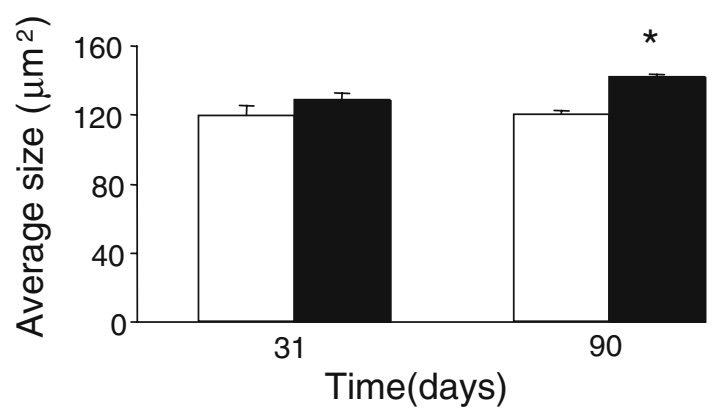

b
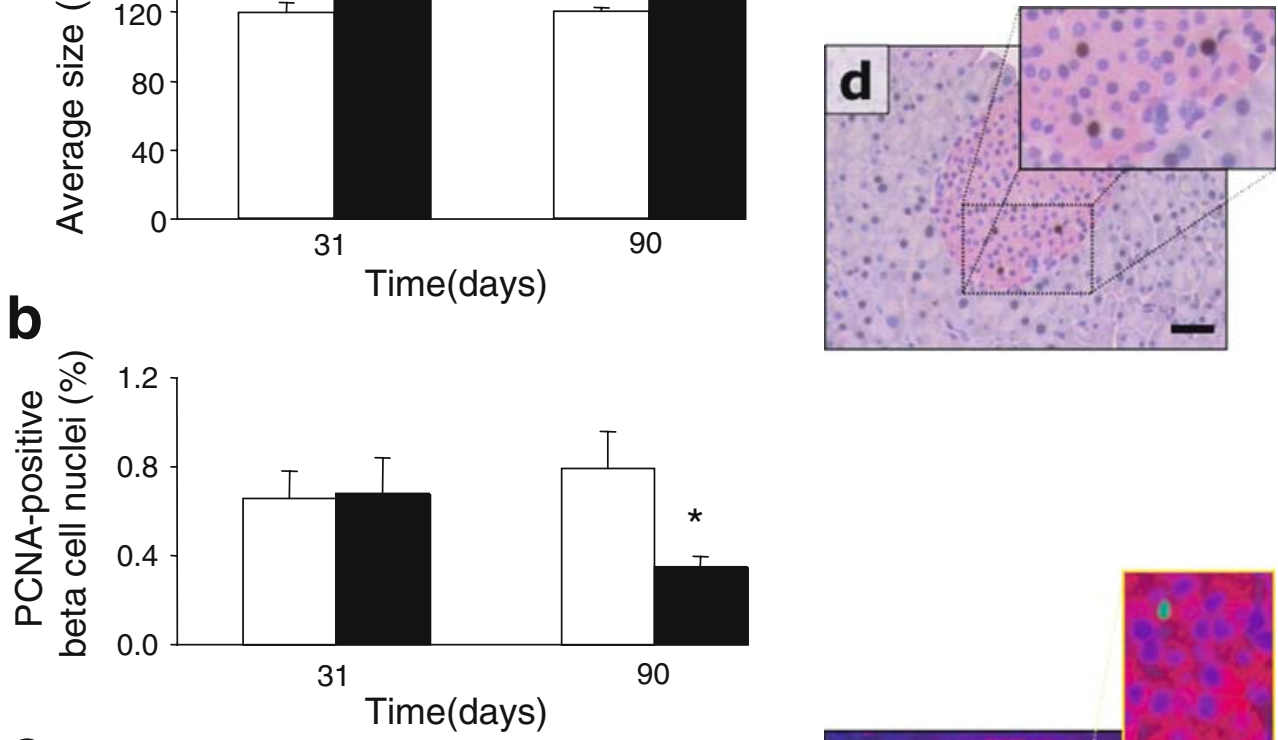

C
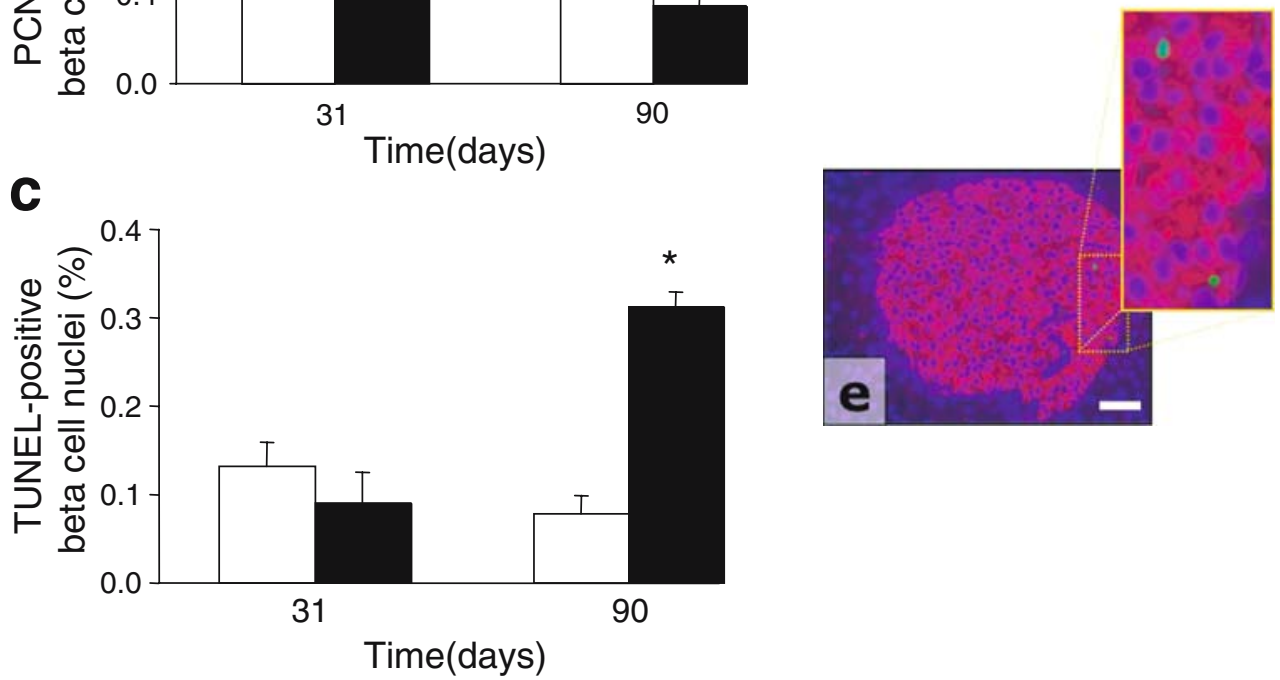

demands and altered hormonal milieu [21, 22]. However, shortly after birth, when the hormonal environment and metabolic demands revert to the non-pregnant state, the expanded beta cell mass involutes, returning to normal levels through beta cell atrophy, increased beta cell apoptosis and decreased beta cell replication [22]. This mirrors quite closely what we have observed in the setting of continual stimulation of islet neogenesis.

The dynamic and highly complex nature of these homeostatic mechanisms is highlighted by the increase in average beta cell size in those animals treated with the Reg3 family member INGAP ${ }^{104-118}$ for 90 days. This is perhaps somewhat counterintuitive, since beta cell hypertrophy would contribute to an expansion of the beta cell mass, not involution, as was seen in 90-day treated mice. However, this finding must be viewed in the context of an approximate $50 \%$ reduction in beta cell replication concomitant with a fourfold increase in apoptotic beta cell death. This observation of beta cell hypertrophy following 90-day INGAP ${ }^{104-118}$ stimulation is in agreement with what has previously been reported in isolated rodent islets [38]. Interestingly, the over-expression or administration of Reg1 has been shown to lead to an increase in beta cell mass through an increase in beta cell replication, although beta cell size was not assessed in these studies [39-42]. The increase in beta cell replication following Reg1 administration contrasts with our study, as we observed that beta cell mass more than doubled following 31 days of treatment in mice, without a concomitant increase in average beta cell size, PCNA labelling of beta cells, or a decrease in TUNEL-positive beta cells. This suggests that the increase in beta cell mass comes from an increase in islet neogenesis. Thus, INGAP ${ }^{104-118}$ may lead to beta cell mass expansion through a different mechanism than that of the other Reg family members.

Even though enhanced beta cell apoptosis and decreased beta cell proliferation appear to be responsible for the involution of the expanded beta cell mass, the underlying 

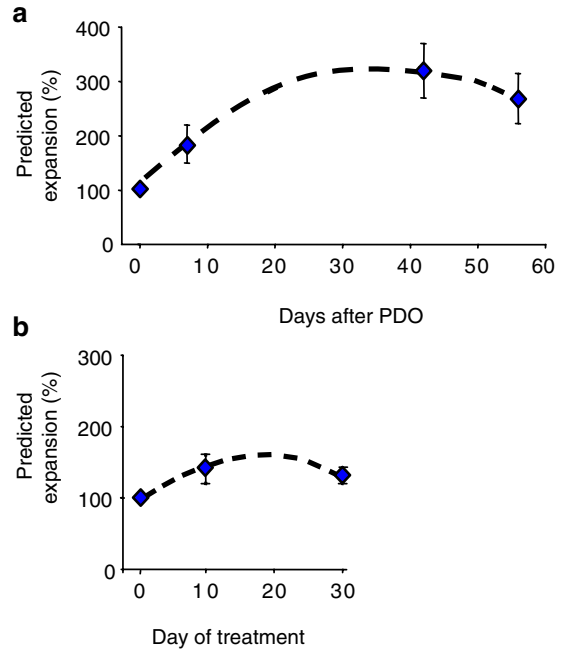

C

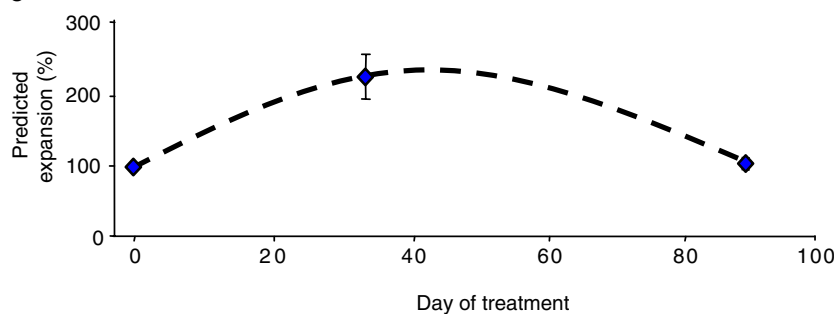

Fig. 7 Predicted beta cell mass expansion curves based on data from partial duct obstructed hamsters (a), hamsters administered $500 \mu \mathrm{g} /$ day INGAP $^{104-118}$ for up to 30 days (b); and CD-1 mice administered INGAP $^{104-118}(2,500 \mu \mathrm{g} /$ day $)$ for up to 90 days (c). All values represent the percentage change from age-matched control hamsters for islet size $\left(\mu \mathrm{m}^{2}\right) \times$ islet density (number per $\left.\mathrm{mm}^{2}\right)(\mathbf{a})$, or total beta cell mass (b and c)

stimulus prompting involution is not readily apparent. The fact that plasma glucose and insulin levels in saline- and INGAP $^{104-118}$-treated hamsters are not significantly different would suggest that other factors are responsible for triggering the process of involution [14].

Beta cell involution can result from removal of a beta cell growth/survival factor, the direct stimulation of beta cell death, or both. For example, administration of gastrin is associated with beta cell growth and decreased beta cell apoptosis in the setting of pancreatic regeneration [15]. This suggests that removal of gastrin-stimulated growth could aid in the involution of beta cell mass. Furthermore, gastrin has been shown to regulate the expression of pancreatic Reg genes, suggesting another means of beta cell mass regulation [43]. On the other hand, elevated levels of cytokines, specifically, IL- $1 \beta$, TNF- $\alpha$ and IFN- $\gamma$, are directly linked to increased beta cell apoptosis [44]. Thus, it is possible that decreased levels of growth factors, as well as increased levels of cytokines could be responsible for initiating the involution of the expanded beta cell mass in our models. We are currently furthering our understanding of the control of endogenous Reg protein and, more specifically, INGAP expression, which may also play a role in these models [45].

Recent information supports the effectiveness of islet neogenesis therapy to reduce $\mathrm{HbA}_{1 \mathrm{c}}$ values [46]. The finding that continual stimulation of islet cell neogenesis does not result in unbridled beta cell mass expansion, suggests that induction of islet neogenesis would be a safe therapy for individuals with diabetes. However, there may still be some issues to resolve. For example, islet neogenesis can occur through one of three pathways: stem cell activation, direct transdifferentiation of mature cell phenotypes, or indirect transdifferentiation of mature cell phenotypes. The direct transdifferentiation pathway is simply the differentiation of a mature cell into an insulin-producing cell without the cell going through a primordial stage, and is suggested by the morphological observation of extra-islet duct- and acinar-associated single beta cells [14, 32, 33]. Indirect transdifferentiation involves the dedifferentiation of previously terminally differentiated cells into a more primitive cell phenotype followed by redifferentiation into a mature beta cell $[15,32,47,48]$. This metaplastic transformation of acinar tissue, leading to the induction of so-called tubular complexes, has been observed in many different models of pancreas regeneration and islet expansion $[13,15,19,32,48,49]$. The significance of these ductlike structures with respect to carcinogenesis remains to be fully explored. Metaplastic transformation of acinar tissue has not been observed in any of the rodent studies of INGAP ${ }^{104-118}$ administration.

Even though the induction of beta cell mass expansion does occur in a regulated manner, there still remains the question as to whether or not pharmaceutical expansion of the insulin-producing cell mass will prove effective in ameliorating both type 1 and type 2 diabetes. Results from clinical Phase IIa proof of principle trials suggest that new beta cells can be formed in the setting of both types [46]. It remains to be determined whether, and to what extent, these newly formed beta cells are protected from the autoimmune insulitis that characterises type 1 diabetes [50].

In conclusion, continual stimulation of islet neogenesis does not lead to unregulated cell expansion. Heightened beta cell apoptosis and diminished beta cell replication serve to regulate induced beta cell mass expansion to meet the body's prevailing needs. This therapeutic approach seems to currently have the greatest potential in the setting of type 2 diabetes, although with advances in immunosuppression, it could be justifiably applied in the setting of type 1 diabetes.

Acknowledgements This work was supported by the Canadian Institutes for Health Research (CIHR), the Canadian Diabetes Association (CDA) and in part by Genome Quebec/Canada. M. A. 
Lipsett is supported by a fellowship from the CIHR and the Diabetic Children's Foundation of Montreal. E. B. Austin is supported by a fellowship from the Research Institute of the McGill University Health Centre. L. Rosenberg is a Chercheur National (National Scientist) of the Fonds de la Recherche Scientifique Quebec (Quebec Fund for Scientific Research). The authors would like to thank the Montreal Chapter of the Lions Club for their support, R. Wang for her work with INGAP ${ }^{104-118}$-treated hamsters, M. Duong and N, Malek for their technical aid, and R. Aikin for helping with this manuscript.

Duality of interest The authors do not have any conflicts of interest that may bias this work.

\section{References}

1. Hellerstrom C (1984) The life story of the pancreatic B cell. Diabetologia 26:393-400

2. Kloppel G, Lohr M, Habich K, Oberholzer M, Heitz PU (1985) Islet pathology and the pathogenesis of type 1 and type 2 diabetes mellitus revisited. Surv Synth Pathol Res 4:110-125

3. Butler AE, Janson J, Bonner-Weir S, Ritzel R, Rizza RA, Butler PC (2003) Beta-cell deficit and increased beta-cell apoptosis in humans with type 2 diabetes. Diabetes 52:102-110

4. The Diabetes Control and Complications Trial Research Group (1993) The effect of intensive treatment of diabetes on the development and progression of long-term complications in insulin-dependent diabetes mellitus. $\mathrm{N}$ Engl J Med 329:977-986

5. UK Prospective Diabetes Study (UKPDS) Group (1998) Intensive blood-glucose control with sulphonylureas or insulin compared with conventional treatment and risk of complications in patients with type 2 diabetes (UKPDS 33). Lancet 352:837-853

6. Writing team for the Diabetes Control and Complications Trial/ Epidemiology of Diabetes Interventions and Complications (EDIC) Research Group (2003) Sustained effect of intensive treatment of type 1 diabetes mellitus on development and progression of diabetic nephropathy. JAMA 290:2159-2167

7. Shapiro AM, Lakey JR, Ryan EA et al (2000) Islet transplantation in seven patients with type 1 diabetes mellitus using a glucocorticoid-free immunosuppressive regimen. N Engl J Med 343:230 238

8. Ryan EA, Lakey JR, Rajotte RV et al (2001) Clinical outcomes and insulin secretion after islet transplantation with the Edmonton protocol. Diabetes 50:710-719

9. Sutherland DE, Gruessner RW, Gruessner AC (2001) Pancreas transplantation for treatment of diabetes mellitus. World J Surg $25: 487-496$

10. Ault A (2003) Edmonton's islet success tough to duplicate elsewhere. Lancet 361:2054

11. Ryan EA, Paty BW, Senior PA et al (2005) Five-year follow-up after clinical islet transplantation. Diabetes 54:2060-2069

12. Suarez-Pinzon WL, Yan Y, Power R, Brand SJ, Rabinovitch A (2005) Combination therapy with epidermal growth factor and gastrin increases beta-cell mass and reverses hyperglycemia in diabetic NOD mice. Diabetes 54:2596-2601

13. Brand SJ, Tagerud S, Lambert P et al (2002) Pharmacological treatment of chronic diabetes by stimulating pancreatic beta-cell regeneration with systemic co-administration of EGF and gastrin. Pharmacol Toxicol 91:414-420

14. Rosenberg L, Lipsett M, Yoon JW et al (2004) A pentadecapeptide fragment of islet neogenesis-associated protein increases betacell mass and reverses diabetes in C57BL/6J mice. Ann Surg 240:875-884
15. Rooman I, Lardon J, Bouwens L (2002) Gastrin stimulates betacell neogenesis and increases islet mass from transdifferentiated but not from normal exocrine pancreas tissue. Diabetes 51:686690

16. Lardon J, Bouwens L (2005) Metaplasia in the pancreas. Differentiation 73:278-286

17. Laidlaw GF (1938) Nesidioblastoma, the islet tumor of the pancreas. Am J Pathol 14:125-139

18. Pavelic K, Hrascan R, Kapitanovic S et al (1995) Multiple genetic alterations in malignant metastatic insulinomas. J Pathol 177:395400

19. Wagner M, Luhrs H, Kloppel G, Adler G, Schmid RM (1998) Malignant transformation of duct-like cells originating from acini in transforming growth factor transgenic mice. Gastroenterology 115:1254-1262

20. Kinoshita Y, Ishihara S, Kadowaki Y, Fukui H, Chiba T (2004) Reg protein is a unique growth factor of gastric mucosal cells. J Gastroenterol 39:507-513

21. Parsons JA, Bartke A, Sorenson RL (1995) Number and size of islets of Langerhans in pregnant, human growth hormoneexpressing transgenic, and pituitary dwarf mice: effect of lactogenic hormones. Endocrinology 136:2013-2021

22. Scaglia L, Smith FE, Bonner-Weir S (1995) Apoptosis contributes to the involution of beta cell mass in the post partum rat pancreas. Endocrinology 136:5461-5468

23. Silberstein GB (2001) Postnatal mammary gland morphogenesis. Microsc Res Tech 52:155-162

24. Strange R, Metcalfe T, Thackray L, Dang M (2001) Apoptosis in normal and neoplastic mammary gland development. Microsc Res Tech 52:171-181

25. Furth PA (1999) Introduction: mammary gland involution and apoptosis of mammary epithelial cells. J Mammary Gland Biol Neoplasia 4:123-127

26. Djonov V, Andres AC, Ziemiecki A (2001) Vascular remodelling during the normal and malignant life cycle of the mammary gland. Microsc Res Tech 52:182-189

27. Jerry DJ, Pinkas J, Kuperwasser C, Dickinson ES, Naber SP (1999) Regulation of p53 and its targets during involution of the mammary gland. J Mammary Gland Biol Neoplasia 4:177181

28. Li M, Hu J, Heermeier K, Hennighausen L, Furth PA (1996) Apoptosis and remodeling of mammary gland tissue during involution proceeds through p53-independent pathways. Cell Growth Differ 7:13-20

29. Li M, Liu X, Robinson G et al (1997) Mammary-derived signals activate programmed cell death during the first stage of mammary gland involution. Proc Natl Acad Sci USA 94:3425-3430

30. Rosenberg L, Brown RA, Duguid WP (1983) A new approach to the induction of duct epithelial hyperplasia and nesidioblastosis by cellophane wrapping of the hamster pancreas. J Surg Res 35: 63-72

31. Wang RN, Bouwens L, Kloppel G (1994) Beta-cell proliferation in normal and streptozotocin-treated newborn rats: site, dynamics and capacity. Diabetologia 37:1088-1096

32. Lipsett M, Finegood DT (2002) Beta-cell neogenesis during prolonged hyperglycemia in rats. Diabetes 51:1834-1841

33. Bouwens L, Pipeleers DG (1998) Extra-insular beta cells associated with ductules are frequent in adult human pancreas. Diabetologia 41:629-633

34. Steil GM, Trivedi N, Jonas JC et al (2001) Adaptation of beta-cell mass to substrate oversupply: enhanced function with normal gene expression. Am J Physiol Endocrinol Metab 280:E788E796

35. Scaglia L, Cahill CJ, Finegood DT, Bonner-Weir S (1997) Apoptosis participates in the remodeling of the endocrine pancreas in the neonatal rat. Endocrinology 138:1736-1741 
36. Finegood DT, Scaglia L, Bonner-Weir S (1995) Dynamics of betacell mass in the growing rat pancreas. Estimation with a simple mathematical model. Diabetes 44:249-256

37. Paris M, Bernard-Kargar C, Berthault MF, Bouwens L, Ktorza A (2003) Specific and combined effects of insulin and glucose on functional pancreatic beta-cell mass in vivo in adult rats. Endocrinology 144:2717-2727

38. Borelli MI, Stoppiglia LF, Rezende LF et al (2005) INGAPrelated pentadecapeptide: its modulatory effect upon insulin secretion. Regul Pept 131:97-102

39. Watanabe T, Yonemura Y, Yonekura H et al (1994) Pancreatic beta-cell replication and amelioration of surgical diabetes by Reg protein. Proc Natl Acad Sci USA 91:3589-3592

40. Gross DJ, Weiss L, Reibstein I et al (1998) Amelioration of diabetes in nonobese diabetic mice with advanced disease by linomide-induced immunoregulation combined with Reg protein treatment. Endocrinology 139:2369-2374

41. Unno M, Nata $K$, Noguchi $N$ et al (2002) Production and characterization of Reg knockout mice: reduced proliferation of pancreatic beta-cells in Reg knockout mice. Diabetes 51(Suppl 3): S478-S483

42. Okamoto H (1999) The Reg gene family and Reg proteins: with special attention to the regeneration of pancreatic beta-cells. J Hepatobiliary Pancreat Surg 6:254-262

43. Ashcroft FJ, Varro A, Dimaline R, Dockray GJ (2004) Control of expression of the lectin-like protein Reg-1 by gastrin: role of the
Rho family GTPase RhoA and a C-rich promoter element. Biochem J 381:397-403

44. Meier JJ, Ritzel RA, Maedler K, Gurlo T, Butler PC (2006) Increased vulnerability of newly forming beta cells to cytokineinduced cell death. Diabetologia 49:83-89

45. Petropavlovskaia M, Makhlin J, Sampalis J, Rosenberg L (2006) Development of an in vitro pancreatic tissue model to study regulation of islet neogenesis associated protein (INGAP) expression. J Endocrinol (in press)

46. Lipsett M, Hanley S, Castellarin M et al (2006) The role of islet neogenesis-associated protein (INGAP) in islet neogenesis. Cell Biochem Biophys (in press)

47. Bonner-Weir S, Baxter LA, Schuppin GT, Smith FE (1993) A second pathway for regeneration of adult exocrine and endocrine pancreas. A possible recapitulation of embryonic development. Diabetes 42:1715-1720

48. Wang GS, Rosenberg L, Scott FW (2005) Tubular complexes as a source for islet neogenesis in the pancreas of diabetes-prone BB rats. Lab Invest 85:675-688

49. Gu D, Sarvetnick N (1993) Epithelial cell proliferation and islet neogenesis in IFN-g transgenic mice. Development 118:33-46

50. Meier JJ, Bhushan A, Butler AE, Rizza RA, Butler PC (2005) Sustained beta cell apoptosis in patients with long-standing type 1 diabetes: indirect evidence for islet regeneration? Diabetologia 48:2221-2228 